症例

初診時頸部リンパ節転移をきたしていた腹膜悪性中皮腫の 1 例

JA 尾道総合病院外科

$\begin{array}{llllllllll}\text { 楠 } & \text { 部 } & \text { 潤 } & \text { 福 } & \text { 田 } & \text { 敏 } & \text { 勝 } & \text { 黒 } & \text { 田 } & \text { 義 } \\ \text { 則 } \\ \text { 倉 }\end{array}$

症例は78歳, 男性. 40 年間鋳物業に従事した職歴がある. 初診時, 左頸部から鎖骨上 窝にかけて $1.5 \mathrm{~cm}$ 大のリンパ節を数珠状に触知し, 上腹部正中には非可動性, 表面凸凹 を伴う児頭大の巨大腫瘤を触知した．CT 検查で頸部から縦隔にかけてリンパ節の腫大 を認め, 左上腹部を中心に周囲臟器への浸潤を伴う巨大腫瘤を認めた。頸部リンパ節生 検で malignant GIST を疑われ，腹部の巨大腫瘤の外科的切除を試みたが非治癒切除と なった，摘出された腹部腫瘤は病理学的に腹膜悪性中皮腫と診断された。悪性中皮腫は 胸膜, 腹膜, 心亳, 精巣䩪膜に発生する稀な腫湯で, 発生にはアスベスト曝露が関連す るとされ, 近年のアスベスト污染に伴いその発生は増加傾向にある. 腹水・腹部腫㿔な どの症状を認め, 確定診断に苦渋する症例では腹膜悪性中皮腫も鑑別診断として念頭に おく必要がある。

索引用語：腹膜悪性中皮腫, 腹腔内巨大腫瘤, 钼部リンパ節転移

\section{緒言}

悪性中皮腫は胸膜, 腹膜, 心衰, 精巣鞘膜に発生す る悪性腫瘍である。胸膜発生例が最も多く, 腹膜発生 例は20 〜 $40^{\circ}{ }^{\circ}$ と, その発生頻度はさらに低い" ${ }^{11}$. 疫学的 にアスベスト曝露が発生原因となることが明らかにさ れており,近年のアスベスト污染の搪がりを反映して, 悪性中皮腫の発生頻度は増加傾向にある21. 今回われ われは, 腹部巨大腫瘦を呈し術前診断に苦渋した腹膜 悪性中皮腫の1例を経験したので若干の文献的考察を 加えて報告する。

症例

症例：78歳, 男性.

主訴：体重減少，無痛性腹部腫瘤.

現病歴：6力月で $5 \mathrm{~kg}$ の体重減少を認め, 手術 2 力 月前より腹部腫瘤を自覚していた。手術 1 カ月前に感 冒のため近医を受診した際に腹部腫溜を指摘され, 当 院を紹介された。

職業歴：鋳物業に 40 年間従事.

入院時現症：身長 $156 \mathrm{~cm}$, 体重 $52.5 \mathrm{~kg}$, 体温 $36.5 \mathrm{C}$,

2006 年 3 月 27 日受付 2006 年 4 月 12 日採用

〈所属施設住所〉

厂722-0002 尾道市古浜町 7-19
血圧130/72mmHg, 脈拍 80 回/分整, 貧血・黄疸なし, 左頸部から鎖骨上窝に $1.5 \mathrm{~cm}$ 大のリンパ節を数珠状 に触知, 腹部腸雑音あり, 上腹部に可動性にそしく表 面凸凹を伴う $10 \mathrm{~cm} \times 20 \mathrm{~cm}$ 大の無痛性腫瘤を触知し て，直腸診では直腸膀胱窝に腫瘾性病変を触知した。

入院時検查所見 : CRP 8.43mg/dl, IL-2R 1,070U/ $\mathrm{ml}$ と上昇を認める以外, 一般血液検査, 血液生化学検 查, 血清学的検查に異常なく, 腫瘍マーカーは AFP, PIVKA-II，CEA，CA19-9とも正常範囲内だった。

胸部単純 $\mathrm{X}$ 線所見：右第 1 弓の突出を認め, 大動脈 弓とのシルエットサインは陽性だった。

胸部 CT 所見：鎖骨上窩から綐隔にかけてリンパ節 が累々と腫大していた（図1）。

腹部 CT 所見：腹部では胃体部大彎に接して，最大 径 $20 \mathrm{~cm}$ 大の内部濃度が不均一な巨大腫瘤を認めた。 左副腎の腫大を認め転移が疑われ, 肝左葉, 膵および 左腎への直接浸潤が疑われた。また，腰椎 L5棘突起が 溶骨性変化を伴って㧍り骨転移も疑われた（図2).

胃内視鏡検査所見：壁外性の圧排を認めたが，粘膜 の異常は認めなかった.

頸部リンパ節生検病理組織所見：HE 染色ではリ ンパ節構造を破壊して異型細胞が胞巣状に增殖する像 を認めた。免疫組織化学染色でリンパ球マーカー 

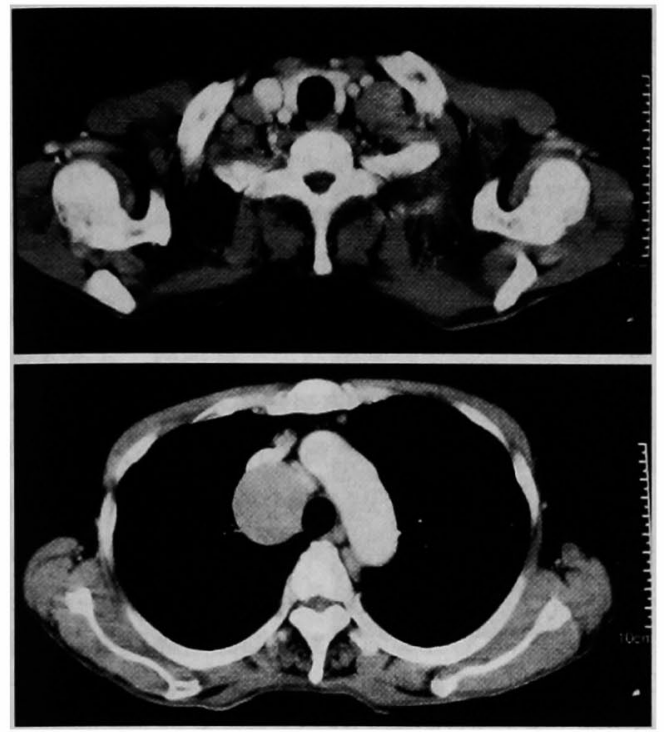

図 1 初診時顁部, 胸部 CT：上）銷骨上窝に $2.5 \mathrm{~cm}$ 大のリンパ節腫大を認めた。 下)気管前リンパ節は $4.5 \mathrm{~cm}$ 大に腫大していた。

（LCA，CD3，S100蛋白など）および上皮細胞マーカ 一 (cytokeratin, EMA) は陰性であったが, 間葉細胞 マーカー (Vimentin 染色) が陽性であり，かつ c-kit 染色弱陽性であった。胃壁に発生した腫晹の転移の可 能性が高いことと合わせ考え, metastatic epithelioid malignant GIST と診断された. 以上より，原発巣の 可及的切除後にメシル酸イマチニブを投与する目的で 手術を施行した.

手術所見 : 全身麻酔下に上腹部正中切開にて開腹し たところ, 中等量の淡血性腹水および腹膜播種と考え られる大豆大の多発結節を認めた。腫崵の発生部位は 同定困難だったが胃後壁に連続して存在し, 周囲藏器 に浸潤していた，腫瘍は易出血性であり，大彎側の胃 壁および横行結腸を一部合併切除する形で全腫演の約 1/3を切除して手術を終了した。

摘出標本所見: 可及的に切除した腫湯重量は1,024 $\mathrm{g}, 19 \mathrm{~cm} \times 16 \mathrm{~cm} \times 10 \mathrm{~cm}$ 大, 表面は不整で灰白色を呈 し, 割面にて出血壊死を認めた。

病理組織所見：HE染色では腫瘍細胞の胞巣状あ るいは乳頭状の増殖を認め, 部分的には豊富な膠原線 維の増生を伴って紡鍾形の腫崵細胞が錯綜して増殖す る像を伴っており, 二相型腹膜悪性中皮腫と考えられ た(図 3 )。免疫組織化学染色では上皮性成分, 間質性 成分ともに上皮細胞マーカー (Cytokeratin, AE1)

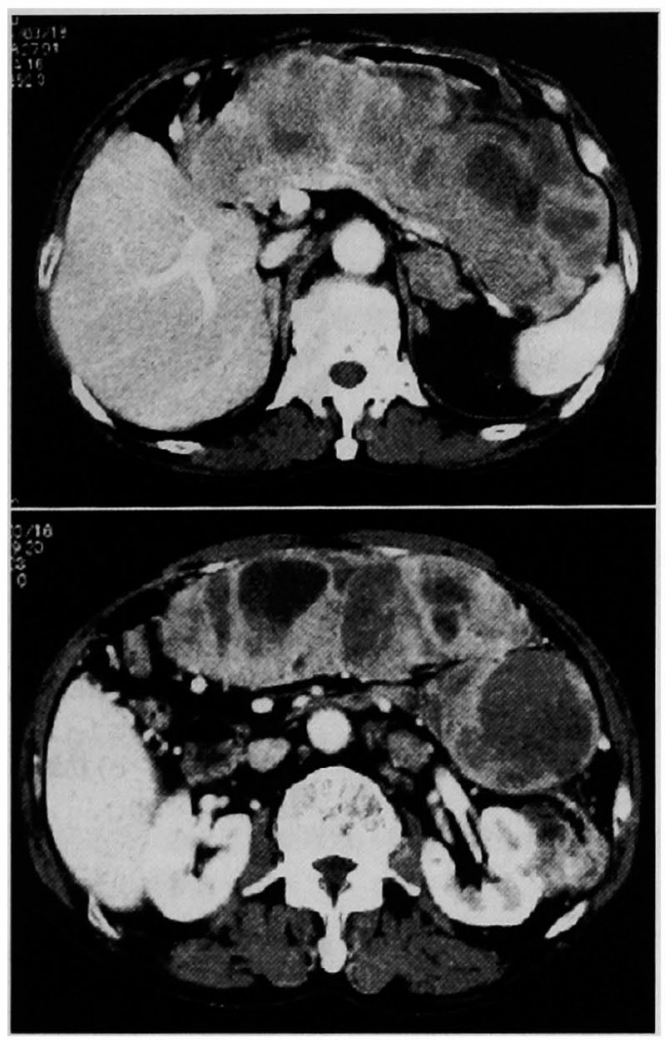

図 2 初診時腹部 CT：上)胃は腹側に圧排され, 胃体 部大鹚側に接するように最大径 $20 \mathrm{~cm}$ 大の巨大腫瘤 を認めた。 また, 左副腎は腫大していた。下)左腎 への直接浸潤が疑われた。

AE3）および間葉細胞マーカー（Vimentin）の免疫活 性が陽性であった（図 4).

術後経過：術後経過は良好であったが, 非治癒切除 に終わったことおよび中皮腫が予後不良の疾患である ことから, 術後はQOLを考慮し, 術後19日目より GEM $(1,200 \mathrm{mg})$ 単剂療法を導入した. しかし 2 クー ル投与後に施行したCT で術前以上の腫湟増殖を認 め, 以後は本人の希望でベストサポートケアとし, 術 後 7 カ月で腫第死した. 剖検は許可されなかった。

\section{考察}

1999年のWHO 腫劰組織分類第 3 版により良性の 中皮細胞腫揚はアデノマトイド腫瘍に分類されること になり，中皮腫といえば全て悪性中皮腫をさすように なった ${ }^{3)}$. 悪性中皮腫は胸膜, 腹膜, 心膜および精巣鞘 膜から発生する稀な悪性腫煌で, 胸膜発生例が最も多 く, 腹膜発生例は全体の $1 / 5$ から $1 / 3$ 程度である゙!. 全悪 性腫瘍の約 $0.2 \%$ 発生頻度であり ${ }^{5)}$ 予後は極めて不 


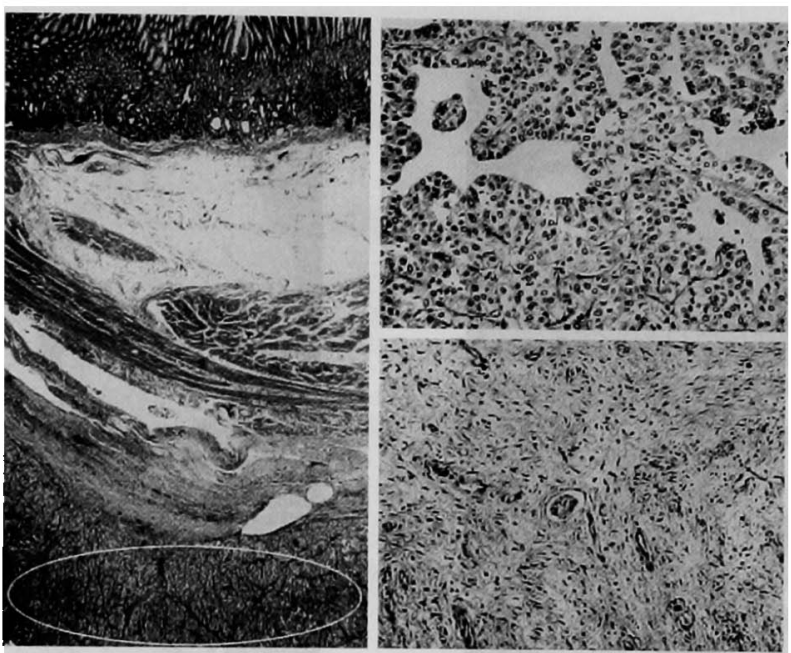

図 3 病理組織（HE 染色）：a）胃の漿膜に連続して腫瘍細胞 の增殖を認めた $(\times 1)$. b) 乳頭状に增殖する上皮性組織を認 めた $(\times 10)$ ，c $)$ 紡錘形細胞が錯綜して増殖した肉腫性組織を 認めた $(\times 10)$.

$a \mid \frac{b}{c}$

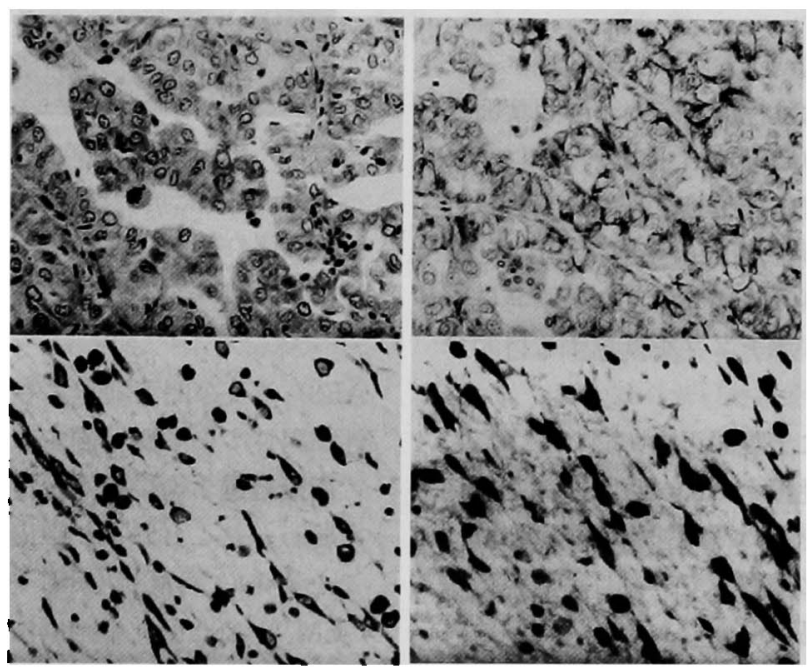

図 4 病理組織：左：Vimentin 染色（×20）は上皮性組織（上） および肉腫性組織 (下) ともに陽性を示した. 右；Cytokeratin 染色 $(\times 20)$ は上皮性組織 (上) および肉腫性組織 (下) ともに 陽性を示した。

良とされる. Wagner らの報告6以来，アスベスト曝簬 が悪性中皮腫の発生原因となることが疫学的に明らか になり, 胸膜悪性中皮腫は環境污染などによる低濃度 曝露者に多く，腹膜悪性中皮腫は職業的な高浱度曝露 者に多いとの報告》もある。アスベスト曝露から悪性
中皮腫発生までの潜伏期間は30〜 40年と長く，わが国 では1960年代よりアスベストの輸入量が急増したこと 加ら，悪性中皮腫発生頻度は今後さらに增加すること が憂慮される.

腹膜悪性中皮腫の自覚症状としては腹部膨满・腹部 
膨隆が50\%以上を占めるが，腫場の占拠部位は腹腔内 のあらゆる部位にわたるため, 腹痛, 食欲不振, 発熱, 便通異常, 嘔吐, 下血, 腰痛, るいそう, 尿閉など多 彩な症状を呈する．他覚的所見では腹水貯留を $90 \%$ 以 上の症例に認める ${ }^{8)}$. CT 検査は腫瘍の広がりの診断, 転移巣の有無に関して有用とされ, 核医学検査, 血管 造影, FDG-PET ${ }^{9}$ が病変の描出に有用であったとする 報告もある。腹腔鏡下生検が診断に有用であったとの 報告5もあるが，その診断確定率は生検された症例の 64\%であり，採取された微小な組織では確定診断に至 るのは困難な場合も多いといえる。また，腹水細胞診 では反応性中皮細胞や腺癌細胞との鑑別が困難な場合 が多く，確定診断には至りにくい湟とされる。

従来, 中皮腫は肉眼的に限局型とびまん型に分類さ れてきたが，良性限局型とされてきた腫瘍は solitary fibrous tumor（环立性線維性腫場）とよばれ，アスべ ストへの曝露歷は見出されないことから，中皮腫とは 異なる腫瘍と考えられるようになった ${ }^{10)}$. 組織学的に は，上皮型，肉腫型，二相型の 3 型に分類される. 同 一腫瘍内に上皮型と肉腫型の組織像が混在する二相型 の組織像は, 悪性中皮腫以外の腫煌では滑膜肉腫でみ られるが，滑膜肉腫が獎膜に発生することはなく，発 生部位を考慮すれば容易に鑑別できるが"1)，上皮型中 皮腫は腺癌との鑑別が, 肉腫型中皮腫はその他の肉腫 との鑑別が問題となる．上皮型中皮腫と腺癌との鑑別 ては，ヒアルロニダーゼによって消化される colloid iron 染色陽性や Alcian blue 染色陽性のヒアルロン酸 を主体とする酸性粘液多糖類の産生を証明することが 有用とされ, 免疫組織化学的染色では近年, D2-40や calretinin が中皮腫の陽性マーカーとして注目されて いる ${ }^{12)}$.肉腫型中皮腫と肉腫との鑑別では,腫瘍細胞の 紐胞質に calretinin や cytokeratin の陽性所見を見出 すことが重要である'”。

治療に関しては可及的外科切除後に CDDP 腹腔内 投与を含めた抗癌郕多剤併用療法が基本とされ, $\mathrm{CDDP}$ 腹腔内投与 $+5-\mathrm{FU}$ 併用療法で 5 年以上生存し た症例 ${ }^{13}$ や $\mathrm{CDDP}+\mathrm{GEM}$ 併用化学療法で QOL を維 持しながら治療しえた症例の報告もある。しかし末だ 有効な治療は確立されていないのが現状である。

本症例は $I L-2 R$ 上昇に加え腹部腫㿔および頸部か ら縦隔リンパ節の腫脹を認めたため, 腹腔内原発悪性 リンパ腫を疑った。しかし，頸部リンパ節生検では epithelioid malignant GIST の転移が疑われた．低分 化の上皮型悪性中皮腫の転移であったと考えられる
が, 定型的な二相型でない場合には生検組織の病理組 織検索でも術前診断は困難な場合がある．腹膜悪性中 皮腫の剖検例の検討では，その50\%に転移がみられ， 転移巣としてのリンパ節では腹腔内リンパ節, 䳔径部 リンパ節, 胸部リンパ節, 腋窝リンパ節が挙げられ, 蔵器転移は肝, 肺にみられることが多いとされてい る ${ }^{14)}$. 検索した範囲内では腹膜悪性中皮腫が初診時に 頸部リンパ節転移をきたしていた症例の報告はなかっ た.

\section{結語}

腹部巨大腫瘤を呈し，初診時に頸部リンパ節転移を きたしていた腹膜悪性中皮腫の 1 例を経験した。悪性 中皮腫はアスベスト污染の拡がりに関連して今後の発 生頻度の增加が危惧されるため, 腹水・腹部腫㿔など の症状を認め確定診断に苦涉する症例は, 腹膜悪性中 皮腫も鑑別診断として念頭におく必要がある.

謝 辞

稿を終えるにあたり御指導頂いた尾道総合病院病理部米 原修治先生に深謝致します。

\section{文献}

1) Liu YC, Kuo YL, Yu CP, et al : Primary Malignant Mesothelioma of the Greater Omentum : Report of a Case. Surg Today $34: 780-783$, 2004

2) Battifora H, McCaughey WT : Tumors of the Serosal Membranes. Ed. by AFIP, Washington DC, 1995, pl7-88

3) Travis WD, Colby TV, Corrin B, et al: Histological Typing of Lung and Pleural Tumors, $3^{\text {rd }}$ ed., WHO, Geneva, 1999, p51-54

4) Sugarbaker PH, Acherman YI, Gonzalez-Moreno $S$, et al: Diagnosis and Treatment of Peritoneal Mesothelioma: The Washington Cancer Institute Experience. Seminors in Oncology $29: 51-61,2002$

5）佐々木正道：悪性中皮腫の病理。病理と臨 7 ： 709-719, 1989

6) Wagner JC, Sleggs CA, Marchand P:Diffuse pleural mesothelioma and asbestos exposure in the North Western Cape Province. Br J Ind Med 17:260-271, 1960

7) Selikoff IJ:Asbestoa-associated disease in occupational respiratory disease. In Public Health and Prevented medicine. $11^{\text {th }}$ ed., Ap- 
pleton-Century-Croft, New York, 1980

8）仲 紘嗣, 仲 綾子：日本におりる腹膜悪性中皮 腫の臨床報告100例に関する臨床病理学的検討. 癌 の臨床 $30: 1-10,1984$

9）後藤靖和, 河崎 敦, 山口由美子他：FDG-PET が 診断に有用てあった悪性腹膜中皮腫の 1 例. 日消 誌 $102: 929-933,2005$

10）井内康輝：アスベスト曝露による呼吸障害，広島 医 $58: 589-597,2005$

11）米原修治：悪性中皮腫の病理, 病理と臨 $17 ： 1$ -13, 1996

12) Chu AY, Litzky LA, PashaTL, et al : Utility of
D2-40, a novel mesothelial marker, in the diag nosis of malignant mesothlioma. Mod Patol 18: $105-110,2005$

13）小倉 修, 野間秀歳, 今村芳郎他：CDDP と5-FU の併用療法が奏効し長期生存が得られたびまん性 腹膜悪性中皮腫の 1 例. 日臨外会誌 $66: 2038-$ 2042, 2005

14) Kannerstein $M$, Churg J : Desmoplastic diffuse malignant mesothelioma. In : Fenoglio CM, Wolff M, eds., Progress in surgical pathology, Vol. II, Field-Wood Medical Pub, New York 1980, p19-29

\title{
A CASE REPORT OF DIFFUSE MALIGNANT MESOTHELIOMA WITH NECK LYMPH NODE METASTASES
}

\author{
Junko NAMBU, Toshikatsu FUKUDA, Yoshinori KURODA, Fumito KURANISHI, \\ Manabu SHIMOMURA and Ryuichi HOTTA \\ Department of Surgery, Onomichi General Hospital
}

A 78-year-old man found to have an abdominal mass was referred to our hospital. Abdominal CT scan showed a $20-\mathrm{cm}$ mass occupying the left upper abdomen. Biopsy of a swelling neck lymph node showed metastatic epithelioid malignant GIST. An open laparotomy resection was performed under a diagnosis of malignant GIST of the stomach. As the massive tumor had directly invaded the surrounding organs, it was impossible to perform en bloc resection. A histopathological diagnosis of diffuse malignant peritoneal mesothelioma was made. Malignant mesothelioma is a relatively rare neoplasm and has a very poor prognosis. Epidemiologically, there is a significant evidence of a link between asbestos exposure and mesotheliomas. 